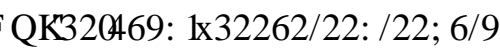

\title{
RELIABILITY ANALYSIS OF WATER DISTRIBUTION SUBSYSTEM
}

\section{ANALIZA NIEZAWODNOŚCI FUNKCJONOWANIA PODSYSTEMU DYSTRYBUCJI WODY}

\author{
Zimoch Izabela \\ Silesian University of Technology, Institute of Water and Sewage Engineering \\ Politechnika Śląska, Instytut Inżynierii Wody i Ścieków \\ 44-100 Gliwice, Konarskiego St. 18, Polska \\ e-mail: izabela.zimoch@polsl.pl
}

\begin{abstract}
This paper presents results of detailed reliability analysis of water distribution subsystem operation of Krakow city. Basis of the research was wide base of information of occurred failures during exploitation (1996-2006). These analysis included evaluation of basic factors such as: failure and renovation intensities, mean recovery time and mean time to failure, availability factor and probability of failure-free operation at any time. Moreover, it was performed wide analysis of failure capability of pipes as a function of its diameter and material. The paper consists also of research results of occurred piping failures reasons and consequences.
\end{abstract}

Keywords: water-pipe network, failure, reliability analysis, failure intensity, repair

Streszczenie: W pracy przedstawiono wyniki oceny niezawodnościowej funkcjonowania systemu dystrybucji wody Krakowa. Podstawę badań stanowiła szeroka baza informacji dotyczących zaistniałych awarii w systemie (1996-2006). Ocena ta obejmowała określenie podstawowych parametrów: parametry strumienia uszkodzeń i odnowy, średnie czasy pracy i naprawy, wskaźnik gotowości oraz prawdopodobieństwo pracy $\mathrm{w}$ dowolnej chwili. Rozpatrzono ponadto zależności pomiędzy awaryjnością przewodów wodociagowych a ich średnicą czy materiałem. Opracowanie obejmuje również wyniki analizy przyczyn i skutków zaistniałych awarii.

Słowa kluczowe: sieć wodociagowa, uszkodzenie, wskaźnik gotowości, analiza niezawodnościowa, intensywność uszkodzeń, odnowa 


\section{RELIABILITY ANALYSIS OF WATER DISTRIBUTION SUBSYSTEM}

\section{Introduction}

The water supply systems (WSS) operation is inseparable relevant with a risk of occurrence of different, undesirable random events, which formative the changing its operation condition. Occurrence frequency of those events as well as its results for customers is significant element of rating the waterworks companies by inhabitants of cities and villages. Independently on dissatisfaction of the inhabitants, breaks of water supply make for the companies a significant loss of incomes that comes from unsold water and also from necessity of ensuring for consumers substitutive water source (costs of delivery water with cisterns). Calculable reliability analysis in changing exploitation conditions, which determines a probability of failurefree operation of the waterworks system, therefore it is now object of concern of water supply system exploiters. The reliability models are used not only in complex exploitation analyses of water supply systems in practice as well as in elaboration of development strategies of the waterworks companies.

The water distribution subsystem (WDS) is the part of WSS, which enables water delivery to the city and distributed directly to final consumers, consists of a water-pipe network situated in the area of the settlement, together with all associated technical objects (network tanks, hydrophores, pumping network station, network equipment). The reliability assessment of distribution subsystem is a complicated and difficult question. It requires considering a wide range of random events. First of all it results from multifunctional of such system. Moreover structure of the system, multitude of different elements consisting of, is another aspect that influences a difficulty of estimating reliability. Small reliability and occurring damages may lead not only to disable operation of water supply system, but also can risk consumers health and lead to other damages of water-pipe enterprises. Qualitative and number estimation of negative events lets draw more precise conclusions and use an engineer performance having in view eliminating them to improve exploitation conditions of distribution subsystem functionality.

Ensuring correct water distribution subsystem operating as well as high guarantee of water supply refers to both: technical part of waterworks 
operation and economical one because increase of surety level causes the increase of additional cost at stage of investment and exploitation. Proper exploitation is based on realization of three fundamental basic groups of actions:

- supervision, which allows gain and gathering information about the object condition,

- attendance, which is a set of action that aims to obtain optimal usage effects, together with maintaining of imposed functionality by the object,

- repairing, this covers a set of actions performed to restore exploitation abilities of the object.

Taking all this into account, application of reliability estimation of system operation, with respect to its technological structure, is essential information for rational managing of water supply system. Therefore waterworks companies exploitation water-pipe network much preferably uses benefits of reliability and safety theory in order to undertake necessary exploitation action on the water pipe network that will allow improvement comfort of company's operation and mainly of inhabitants' life conditions [4].

\section{Parameters of reliability assessment}

The reliability of water pipe networks is a multifunctional operation process. The process relates to continuous providing consumers with water in required quantity and quality, at any moment, under suitable pressure, and whose price will be acceptable by a consumer. Most of engineering objects and devices consisting of the water supply system are classified as so called renewable elements that mean, such that can be taken in processes of running and renovation. The analysis of object exploitation helps determining exploitation states which, if arranged in time domain, illustrates the process of exploitation. In the reliability analysis it is limited number of states only to this which follows from fundamental functionality of examined objects. In practice it means that during determination of the exploitation parameters crucial are only events which cover variation of parameters of object operation. A determining exploitation condition, definite as reliability states, is a ground of selection and estimation of suitable reliability factors of these objects. Two reliability states are distinguished as:

- state of operation, it means full ability

- state of partial or complete unavailability. 
Taking into consideration above exploitation states and specification of objects and water-pipe devices in the reliability analysis of their operating there are defined:

- probability of being in a given state,

- intensity of states appearance,

- mean time of being in a given state.

From waterworks companies and water customer's point of view, it is essential full efficiency of waterworks pipes, it means state, when the pipes do not need any immediate repair, only scheduled works and supplying to customers of WSS water of adequate amount and quality and of required pressure. Therefore it was assumed in WDS analyses two-stage exploitation model. It was distinguished in the accepted reliability model following random events:

- a pipe can pass through one state to another,

- unavailability state is removed that all failed elements are repaired,

- as a result of repair pipe passes from any unavailability state (partial or complete) into operational one i.e. full ability.

To describe the above exploitation model it is denoted by: probability of failure-free operation $R(t)$ and renovation probability $R_{o}(t)$, mean time to failure $T_{p}$ and mean recovery time $T_{o}$, as well as parameters of failure intensity $\omega$ and renovation intensity $\mu$.

Table 1. Reliability factors

\begin{tabular}{|l|l|}
\hline Reliability factors & Math formulas \\
\hline Mean time to failure & $T_{p}=\frac{1}{k+z}\left(\sum_{i=1}^{k} t_{p i}+z \cdot t\right)$ \\
\hline Mean recovery time & $T_{o}=\frac{1}{n_{o}} \sum_{i=1}^{n_{0}} t_{o i}$ \\
\hline Parameter of failure intensity & $\omega=\frac{1}{T_{p}}$ \\
\hline Renovation intensity parameter & $\mu=\frac{1}{T_{o}}$ \\
\hline Probability of failure-free operation & $R(t)=P\left(T_{p}^{\prime} \geq t\right)=\exp (-\omega \cdot t)$ \\
\hline Renovation probability & $R_{o}(t)=1-\exp (-\omega \cdot t)$ \\
\hline
\end{tabular}

Knowing the probability distribution of the random variable - time to failure $T_{p}$, allows for calculation of these parameters. The flux of the water pipe elements' failures is a flux without consequences, singular and steady, and the renovation process is a Poisson process, for which the time is exponentially distributed $[1,3,4]$. The above fact allows for the estimation of these variables according to the formulas in table 1 . These random variables 
are reliability-dependent factors, they are related to number of operational periods of failing objects $(k)$, value of $\mathrm{i}^{\text {th }}$ operational period $\left(t_{p i}\right)$, observation period $(t)$, time of lasting $\mathrm{i}^{\text {th }}$ renewal $\left(t_{o i}\right)$,number of operational periods of unfailing objects $(z)$ as well as number of failures during tested period $\left(n_{o}\right)$. The failure intensity for linear engineering objects, the water-pipe network are, is an unconditional probability per unit of pipe's length $(L)$ occurring $n_{o}$ - object failure times in observation period $(t)(7)$ :

$\omega(t)=\frac{n_{o}}{L \cdot t}$

Above mentioned parameters define o global reliability index, which is the stationary ability factor $K_{g}$. This availability factor is reliability parameter of probability that engineering object, system or subsystem will be ready to operate at any moment. In practice this factor means probabilistic estimation of object, system or subsystem availability in the range of execution of a given task (8):

$K_{g}=\frac{T_{p}}{T_{p}+T_{o}}=\frac{\mu}{\omega+\mu}$

Practical use of presented formulas in reliability assessment of water-pipe network operation bases on indispensable information obtained from WDS exploitation. Source date are failure protocols, failure cards, exploit books, operating books of a machine, log of standby service, registers of failures etc. Above documentation should contains data such as: date and hour of failure, repair, overhaul etc., lasting time, description of the event containing type of failure and its effects for the subsystem or whole WSS. Unfortunately, information obtained form exploitation are not always enough, what considerably makes difficulty to perform full analysis. They are not systematic and sometimes allow only stating a fact of failure without any numerous data useful in finding appropriate factors

\section{The water distribution subsystem of Krakow city}

Currently the water distribution subsystem consists of the complex waterpipe network with many storage tanks. Krakow is divided into separate water-pipe zones of supply, fed from independent sources which are 4 surface water intakes supplied from: the Raba River, the Rudawa River, the Dłubnia River and the Sanka River and one underground intake placed in Mistrzejowice. Localization and technical solutions of supply systems (in normal conditions of exploitation) deliver on average 169 tys. ${ }^{3}$ of water to the network. This guaranties a reliable operation of the water supply subsystem to the city. In Cracow water is delivered to the consumers 
through a complex system of transit $(\varnothing 1400$, length $18 \mathrm{~km})$, main network $(\varnothing 1200-\varnothing 330$, length $247,9 \mathrm{~km})$ and distribution network $(\varnothing 280-\varnothing 80$, length $1131,1 \mathrm{~km})$, as well as house waterworks terminals $(\varnothing 100-\varnothing 25$, length $472,9 \mathrm{~km}$ ). The total length of the network in the area serviced by City of Cracow Water and Sewage Utility Company is $1869,9 \mathrm{~km}$. It is characterized by substantial age and materials differentiation. Most water pipes were built after 1975 (56\% of total length). Also a substantial percentage of the water pipes were built in the 1990s (26\% of total length), using modern materials and technology, which significantly increases their technical value. The most significant part in material structure takes steel pipes, being $32 \%$ of total length of the network and next pipes made of cast iron $(26 \%)$ and PCV $(23 \%)$. There are 11 storage tanks, of total capacity $276200 \mathrm{~m}^{3}$, that are inseparable elements of the WDS.

\section{The reliability analysis of Krakow's WDS}

The water distribution subsystem of Krakow city is a large and extensive one, with complicated topology and different types of utilities. Relatively frequent failures are caused by many-year exploitation of the pipeline, by negative influence of environment and often by low quality of materials, of which the pipeline was made after World War II. In the course of the year Waterworks Company in Krakow registers about 1850 failures of the waterpipe network. These failures apply to damage of water pipe casing, pipe connection as well as its utility failures. Performed analysis of pipe network failure has shown that most common reason of pipeline failures is corrosion damage (fig.1). Moreover it was stated dependency between intensity of failures and season of the year. Relatively the largest number of failures falls to autumn-winter period.

Performed reliability analysis paid attention to estimation and classification of operating conditions of water distribution subsystem of Krakow city. Operation study on reliability was conducted in $2004-2006$ during the research project $\mathrm{PB}$ no. 5T07E 04425 realization [5]. Moreover, the analysis was based on archival data (1996 - 2006) taken from Exploitation Cards of water pipe network in Krakow [2]. These data were made available by Krakow's Water Company. The research was carrying out on total length of pipes with diameters from Ø25 to Ø1400. Conditions of research were arranged for accuracy of $\delta=0.1$ (relative error) of estimated reliability measures with confidence level $\beta=0.95$.

Studies were bidirectional. First direction of study contained reliability analysis of water-pipelines in regard to its building material as well as pipe 
function in water distribution system in the city (dividing them into three groups: house waterworks terminals, distribution and main networks - table

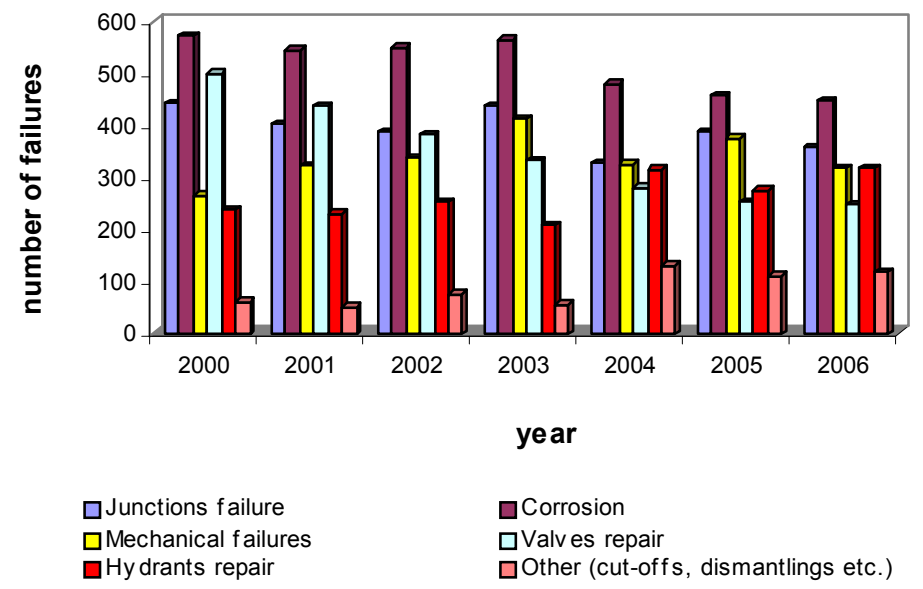

Fig. 1. The failure frequency of the water-pipe network as a function of damage type during 2000-2006

2). Second aspect of study was preliminary reliability estimation of separated linear elements of the distribution subsystem.

For every pipe (with specified diameter and made of concrete material) realizations of following random variables were determined: time to failure $T_{p}[\mathrm{~h}]$, recovery time $T_{o}[\mathrm{~h}]$, repair time $T_{n}[\mathrm{~h}]$, and time of waiting for repair $T_{z}[\mathrm{~h}]$. All statistical analyses were carried out with use of STATISTICA PL software package. The Kruskal-Wallis Test results confirmed the assumption null hypothesis $\mathrm{H}_{0}$, ordered samples concern homogeneous elements from the same population. So, random variables verified in this way are inputs for the evaluation of empirical reliability characteristics (table 2).

Obtained results of water-pipe damages analysis were related to recommended values of the failure intensity parameter according to European criteria:

- the main network - less than $\leq 0.3$ failure/axkm,

- the distribution network - les than 0.5 failure/axkm,

- the house waterworks terminals - less than 1.0 failure/axkm. 
Table 2. Empirical reliability parameters of water-pipe network in Krakow

\begin{tabular}{|c|c|c|c|}
\hline \multirow[b]{2}{*}{$\begin{array}{c}\text { Parameter } \\
\text { s } \\
\end{array}$} & \multicolumn{3}{|c|}{ Steel water pipes } \\
\hline & $\begin{array}{l}\text { House waterworks } \\
\text { terminals }\end{array}$ & $\begin{array}{l}\text { Distribution } \\
\text { network }\end{array}$ & Main network \\
\hline$T_{p}[\mathrm{~h}]$ & 453.13 & 444.19 & 1413.82 \\
\hline$\omega\left[\mathbf{a}^{-1} \mathbf{k m}^{-1}\right]$ & 0.292 & 0.342 & 0.028 \\
\hline$T_{o}[\mathrm{~h}]$ & 26.05 & 29.05 & 47.41 \\
\hline$T_{n}[\mathrm{~h}]$ & 7.41 & 9.24 & 8.77 \\
\hline$T_{z}[\mathbf{h}]$ & 18.65 & 19.81 & 38.64 \\
\hline$\mu\left[\mathbf{h}^{-1}\right]$ & 0.038 & 0.034 & 0.021 \\
\hline$R(t)$ & $R(t)=\exp (-0.00221 \cdot t)$ & $R(t)=\exp (-0.00225 \cdot t)$ & $R(t)=\exp (-0.0007 \cdot t)$ \\
\hline & \multicolumn{3}{|c|}{ Cast iron water pipes } \\
\hline$T_{p}[\mathbf{h}]$ & 448.92 & 42.86 & 543.58 \\
\hline$\omega\left[\mathbf{a}^{-1} \mathbf{k m}^{-1}\right]$ & 1.698 & 1.053 & 0.422 \\
\hline$T_{o}[\mathrm{~h}]$ & 25.49 & 38.82 & 52.40 \\
\hline$T_{n}[\mathrm{~h}]$ & 6.56 & 6.85 & 8.13 \\
\hline $\boldsymbol{T}_{z}[\mathbf{h}]$ & 18.92 & 31.97 & 44.27 \\
\hline$\mu\left[\mathbf{h}^{-1}\right]$ & 0.039 & 0.026 & 0.019 \\
\hline$R(t)$ & $R(t)=\exp (-0.02218 t)$ & $R(t)=\exp (-0.02333 \cdot t)$ & $R(t)=\exp (-0.00184 \cdot t)$ \\
\hline
\end{tabular}

Analyzing the process of water pipe network failures during 2000-2006 years as a function of material that has the greatest participation in the whole length of the system (32\%) i.e. steel, it is possible to state uniquely that this material is characterized by high-reliability in reference to transit and main pipes $(\varnothing 300-\varnothing 1400)$ satisfying the above European standards $\left(\omega_{s t_{-} T M}=0.028\right.$ failure/axkm $<<\omega_{w}(t)=0.3$ failure/axkm). For the rest of steel pipes of the network the failure frequency indexes satisfy required European standards (the distribution network 0.342 failure/axkm and the house waterworks terminals 0.292 failure/axkm. Analyzing the dynamics and type of inefficiency changes one could uniquely state that the average value of the failure intensity was strongly reduced after 2000 year. In the year 19961999 the failure intensities are equal to: 0.095 failure/axkm for the transit and main pipes, 0.699 failure/axkm for the distribution network and 1.434 failure/axkm for the house waterworks terminals [6]. After practical application in 2001 the system of the network management, basing on analyses and conclusions of archival exploitation data concerning failures, the failure intensity of steel distribution network decreased $65 \%$ during only 6 years. 
Results of reliability assessment of cast iron water pipes (table 2) show great frequency of failure. In the year 1996-1999 the failure intensity for ach tape of water pipe networks reached value:

- 0.867 failure/axkm for the main network,

- 2.239 failure/axkm for the distribution network,

- 1.695 failure/axkm for the house waterworks terminals.

The analysis of dynamics changes of cast iron water network pointed out the $52 \%$ failure intensity reducing only of main and distribution networks. However, the failure intensity of house waterworks terminals made of cast iron characterized by the same high level in whole period of reliability research (1996-1999 and 2000-2006). It obtained value 1.698 failures per year and unit length of pipe $(\mathrm{km})$.

In order to identify the distribution of considered random variables for separate networks, there was verified the propriety of assumed null hypothesis $\mathrm{H}_{0}$, on the level of significance $\alpha=0.05$ that the time to failure $T_{p}$ and recovery time $T_{o}$ are distributed exponentially. To the verification of assumed hypotheses the $\chi^{2}$-Pearson was used. Because calculated, for each case of analysis, statistics values $\chi^{2}$ were smaller than critical values, there is no reason to reject these assumed hypotheses. The above analyses allowed finding equations of the probability of failure-free operation $R(t)$ and the renovation probability $R_{o}(t)$ as a function of network exploitation time that are shown in the table 2.

\section{Conclusion}

1. The cost iron water-pipe network is characterized the highest frequency of failure.

2. On reliability of cast-iron pipes decides mainly joint failures. In the Krakow distribution system, cast-iron pipes are old, approaching the expiry term of working life (36\% of pipes in the network are $25-50$-year-old). Majority were connected with pipe bells traditionally tighten with cord and aluminum foil, which failure intensity is greater then connections using new technologies.

3. According to the European standards of water-pipe network failures only the distribution network and the house waterworks terminals made of cost iron don't have required reliability level of operating.

4. Failure intensity of distribution network is over twice greater $((\omega=1.053$ failure/axkm) and home terminal even three times $(\omega=1.698$ failure/axkm) with regard to failure intensity of main and transit networks $(\omega=0.422$ 
failure/axkm). However, the failure intensity for steel pipes is average eleven-times smaller according to this intensity for the distribution network and the house waterworks terminals.

5. From a reliability point of view, it is possible to state that despite the high failure intensity parameter, the water-pipe network generally was characterized by high availability variation. Average value of stationary ability factor for pipes of the main and transit network is equal to 0.940010 and for the house waterworks terminals 0.945953. In the case of the distributing network value of that parameter reach a level 0.7316435 , what results from high failure-rate of pipes with diameter 100 and $150 \mathrm{~mm}$.

6 . The quantity analysis of negative exploitation events in water network allows for precise and rational stating conclusions as well as application of technical operations that will eliminate negative events. Hence described here reliability analysis of WDS (with reference to its technical structure) has not only scientific meaning. This method can be an important practice tool useful in rational management of WSS.

\section{References}

1. Kwietniewski M., Roman M., Kłoss-Trębakiewicz H. Niezawodność wodociagów i kanalizacj. Arkady, Warszawa 1993.

2. MPWiK S.A. Kraków. Materiaty archiwalne 1996-2006.

3. Wieczysty A. i inni. Metody oceny $i$ podnoszenia niezawodności działania komunalnych systemów zaopatrzenia $w$ wodę. Komitet Inżynierii Środowiska PAN, Monografie nr 2, Kraków 2001.

4. Zimoch I. The Water Distribution Subsystem Failures Affects on Krakow's Water Supply System. Materiały konferencyjne : 9-tego Międzynarodowego Sympozium „Water Management and Hydraulik Enginnering," Ottenstein 2005.

5. Zimoch I. Opracowanie modelu niezawodności funkcjonowania systemu zaopatrzenia $w$ wodę(SZW) w aspekcie wtórnego zanieczyszczenia wody $w$ sieci wodociagowej. Sprawozdanie końcowe $\mathrm{z}$ realizacji Projektu Badawczego PB nr 5T07E 044 25, Gliwice 2007. 


\section{ANALIZA NIEZAWODNOŚCIOWA FUNKCJONOWANIA PODSYSTEMU DYSTRYBUCJI WODY}

\section{Wstęp}

$\mathrm{Z}$ funkcjonowaniem systemów zaopatrzenia $\mathrm{w}$ wodę (SZW) jest nierozłącznie związane ryzyko wystąpienia różnego rodzaju niepożądanych zdarzeń losowych, kształtujących zmienne warunki jego eksploatacji. Częstotliwość występowania tych zdarzeń jak i ich skutki dla odbiorców sa istotnym elementem oceny przedsiębiorstw wodociagowych przez mieszkańców miast i wsi. Niezależnie od niezadowolenia mieszkańców, przerwy w dostawie wody stanowią dla tych przedsiębiorstw istotną strate $\mathrm{w}$ postaci nie tylko utraty wpływów $\mathrm{z}$ tytułu niesprzedanej wody, ale również poniesienia kosztów wynikających z konieczności zapewnienia odbiorcom zastępczego źródła wody(koszty dowozu wody cysternami).Wymierna analiza niezawodnościowa określająca prawdopodobieństwo bezawaryjnej pracy systemów wodociągowych, w zmiennych warunkach ich funkcjonowania, znajduje obecnie coraz większe zainteresowanie wśród eksploatatorów SZW. Modele niezawodnościowe są stosowane $\mathrm{w}$ praktyce nie tylko w złożonych analizach eksploatacyjnych systemów zaopatrzenia w wodę ale również przy opracowywaniu strategii rozwojowych firm wodociagowych.

Podsystem dystrybucji wody (PsDyW) buduje sieć wodociaggowa zlokalizowana w obrębie jednostki osadniczej wraz ze wszystkimi towarzyszącymi jej obiektami technicznymi (zbiorniki sieciowe, hydrofornie, pompownie sieciowe, uzbrojenie sieci), która umożliwia rozprowadzenie wody na terenie miasta i doprowadzenie jej bezpośrednio do odbiorców. Ocena niezawodności systemu dystrybucji jest zagadnieniem złożonym i trudnym, wymagającym rozważania szerokiego zakresu zdarzeń losowych. Wynika to przede wszystkim z wielofunkcyjności tego systemu. Ponadto struktura systemu, mnogość różnych elementów go budujących to kolejny aspekt determinujący trudności podejmowanych ocen niezawodnościowych. Mała niezawodność i występujące w związku z tym awarie moga prowadzić nie tylko do przerwania funkcjonowania systemu zaopatrzenia $\mathrm{w}$ wodę lecz także do utraty zdrowia, lub innych istotnych szkód jakie ponoszą przedsiębiorstwa wodociągowe. Jakościowa oraz 
liczbowa ocena negatywnych zdarzeń pozwala na sprecyzowanie wniosków i zastosowanie działań technicznych mających na celu ich eliminację, w celu polepszenia warunków eksploatacyjnych funkcjonowania podsystemu dystrybucji.

Zapewnienie prawidłowej eksploatacji PsDyW oraz wysokiej gwarancji dostawy wody, wiąże się zarówno ze stroną techniczną funkcjonowania systemu wodociagowego jak i ekonomiczna, gdyż podniesienie poziomu gwarancji wymusza zwykle dodatkowe nakłady finansowe zarówno na etapie inwestycji jak i eksploatacji. Prawidłowa eksploatacja PsDyW, jak każdego systemu technicznego oparta jest na realizacji trzech podstawowych grup czynności:

- nadzorowanie, pozwalające na pozyskiwanie i gromadzenie informacji o stanie obiektu,

- obsługiwanie, stanowiące zespół czynności zmierzających do uzyskania optymalnych efektów użytkowych, przy jednoczesnym zachowaniu przez obiekt zdolności do wykonywania narzuconej funkcji,

- naprawianie, obejmujące zespół czynności podejmowanych w celu przywrócenia zdolności eksploatacyjnej obiektu.

Wyniki ocen niezawodności pracy systemu wodociągowego $\mathrm{w}$ procesie eksploatacji PsDyW, w odniesieniu do jego struktury technicznej, stanowia cenne narzędzie decyzyjne, dostarczające istotnych informacji dla racjonalnego zarządzania systemem zaopatrzenia $\mathrm{W}$ wodę. Dlatego przedsiębiorstwa wodociaggowe eksploatujące sieć wodociągową coraz chętniej korzystają ze zdobyczy teorii niezawodności i bezpieczeństwa, w celu podjęcia niezbędnych działań eksploatacyjnych na sieci wodociagowej, pozwalających na poprawę komfortu funkcjonowania przedsiębiorstwa ale przede wszystkim warunków życia mieszkańców.

\section{Parametry analizy niezawodnościowej}

Niezawodność SZW a w tym sieci wodociagowej jest procesem wielofunkcyjnym odnoszącym się do ciagłego dostarczania do odbiorcy wody w wymaganej ilości, spełniającej obowiązujące normatywy jej jakości w określonych warunkach pracy i w dowolnej chwili oraz pod odpowiednim ciśnieniem i po akceptowalnej przez konsumenta cenie $1 \mathrm{~m}^{3}$. Większość obiektów technicznych i urządzeń budujących system zaopatrzenia w wodę zliczana jest do tak zwanych elementów odnawialnych, czyli takich, które podlegaja procesowi pracy i odnowy. Analiza procesu eksploatacji obiektu pozwala na wyznaczenie stanów eksploatacyjnych, które uporządkowane w czasie obrazują proces eksploatacji. W badaniach niezawodnościowych 
ogranicza się liczbę stanów, jedynie do tych, które wynikaja $\mathrm{z}$ podstawowych funkcji badanych obiektów. W praktyce oznacza to, ze przy określaniu stanów eksploatacyjnych decydujące są wyłącznie zdarzenia obejmujące istotne zmiany parametrów pracy obiektów. Ustalenie więc warunków eksploatacyjnych, określonych jako stany niezawodnościowe stanowi podstawę doboru i oszacowania odpowiednich wskaźników niezawodności tych obiektów. Wyróżnia się dwa stany niezawodnościowe:

- stan pracy, czyli zdatności całkowitej,

- stan niezdatności częściowej lub całkowitej.

Uwzględniając powyższe stany eksploatacyjne oraz specyfikę obiektów i urządzeń wodociagowych $\mathrm{w}$ analizie niezawodności ich funkcjonowania określa się:

- prawdopodobieństwo przebywania w danym stanie,

- intensywność występowania stanów,

- średni czas przebywania w danym stanie.

Parametry pracy sieci wodociągowej mają charakter losowy, dlatego warunkiem właściwego przeprowadzenia badań niezawodnościowych podsystemu dystrybucji wody jest klasyfikacja poszczególnych zdarzeń eksploatacyjnych do odpowiednich stanów eksploatacji. Z punktu widzenia przedsiębiorstw wodociaggowych jak i odbiorców wody istotna jest pełna sprawność przewodów wodociągowych, czyli stan, gdy przewody nie wymagają napraw doraźnych, a jedynie robót planowych oraz dostarczaja użytkownikom systemu SZW wodę w odpowiedniej ilości i jakości, pod wymaganym ciśnieniem. Dlatego $\mathrm{w}$ analizach PsDyW przyjęto model dwustanowy eksploatacji. W przyjętym modelu niezawodnościowym wyróżniono następujące zdarzenia losowe:

- przewód może przejść ze stanu pracy do jednego ze stanów niesprawności,

- stan niezdatności jest usuwany, że wszystkie uszkodzone elementy są naprawiane,

- w wyniku naprawy przewód przechodzi z dowolnego stanu niezdatności (częściowej lub całkowitej) w stan pracy, czyli zdatności pełnej.

Do opisu powyższego modelu eksploatacji sieci wodociagowej określa się: prawdopodobieństwa pracy bezuszkodzeniowej $R(t)$ i odnowy $R_{o}(t)$, średni czas pracy bezuszkodzeniowej $T_{p}$ i średni czas odnowy $T_{o}$, parametr strumienia uszkodzeń $\omega$ oraz intensywność odnowy $\mu$.

Znajomość rozkładów prawdopodobieństwa zmiennej losowej - czas pracy bezuszkodzeniowej $T_{p}$ pozwala na obliczenie powyższych parametrów niezawodnościowych. Strumień uszkodzeń obiektów wodociagowych jest strumieniem bez następstw, pojedynczym i stacjonarnym, a proces odnowy 
jest procesem Poissona, dla którego czas pracy ma rozkład wykładniczy $[1,3,4]$. Powyższy fakt pozwala na estymacje tych wielkości według reguł podanych $\mathrm{w}$ tabeli 1 . Powyższe zmienne losowe są zmiennymi zależnymi, kształtowanymi parametrami eksploatacji: liczba okresów pracy obiektów uszkadzających się $(k)$, wartość i-tego okresu pracy $\left(t_{p i}\right)$, długość okresu obserwacji $(t)$, liczba okresów pracy obiektów nieuszkadzających się (z), liczba niesprawności w badanym okresie eksploatacji $\left(n_{o}\right)$ oraz czas trwania i-tej odnowy $\left(t_{o i}\right)$.

Tabela 1. Parametry niezawodnościowe

\begin{tabular}{|l|ll|}
\hline Wskaźnik niezawodności & Formula \\
\hline Średni czas pracy bezuszkodzeniowej & $T_{p}=\frac{1}{k+z}\left(\sum_{i=1}^{k} t_{p i}+z \cdot t\right)$ & $(1)$ \\
\hline Średni czas odnowy & $T_{o}=\frac{1}{n_{o}} \sum_{i=1}^{n_{0}} t_{o i}$ \\
\hline Parametr strumienia uszkodzeń & $\omega=\frac{1}{T_{p}}$ \\
\hline Parametr strumienia odnowy & $\mu=\frac{1}{T_{o}}$ \\
\hline Prawdopodobieństwo pracy bezuszkodzeniowej & $R(t)=P\left(T_{p}^{\prime} \geq t\right)=\exp (-\omega \cdot t)$ \\
\hline Prawdopodobieństwo odnowy & $R_{o}(t)=1-\exp (-\omega \cdot t)$ & $(5)$ \\
\hline
\end{tabular}

Parametr strumienia uszkodzeń dla liniowych obiektów technicznych, do których zaliczana jest sieć wodociagowa, jest bezwarunkowym prawdopodobieństwem, przypadającym na jednostkę długości przewodu $(L)$, wystąpienia $\left(n_{o}\right)$ uszkodzeń w okresie eksploatacji (t) (7):

$\omega(t)=\frac{n_{o}}{L \cdot t}$

Powyższe wskaźniki określają globalny parametr niezawodności, tzw. wskaźnik gotowości $K_{g}$. Wskaźnik gotowości jest parametrem niezawodnościowym, który wyraża prawdopodobieństwo, że obiekt, system lub podsystem będzie $\mathrm{w}$ stanie zdatności $\mathrm{w}$ dowolnym momencie czasu. W praktyce wskaźnik ten oznacza probabilistyczną ocenę dyspozycyjności obiektu, systemu bądź podsystemu lub układu w zakresie wykonywania danego zadania (8): 


$$
K_{g}=\frac{T_{p}}{T_{p}+T_{o}}=\frac{\mu}{\omega+\mu}
$$

Praktyczne wykorzystania powyższych wzorów w ocenie niezawodnościowej funkcjonowania sieci wodociagowej opiera się na niezbędnych informacjach uzyskanych z eksploatacji PsDyW. Materiałami źródłowymi są protokoły awarii, karty awaryjne, książki eksploatacji, książki pracy maszyn, dzienniki zgłoszeń pogotowia interwencyjnego, rejestry awarii itp. Dokumentacja powyższa winna obejmować dane takie jak: data i godzina wystapienia awarii, naprawy, remontu itp., czas trwania, opis zdarzenia obejmujący rodzaj uszkodzenia oraz skutki awarii dla podsystemu lub całego SZW. Niestety nie zawsze informacje uzyskane z eksploatacji są wyczerpujące, co znacznie utrudnia prowadzenie pełnych analiz. Nie są one prowadzone systematycznie i czasem pozwalają jedynie na stwierdzenie faktu awarii, nie zawierając żadnych danych liczbowych umożliwiających wyznaczenie odpowiednich wskaźników

\section{System dystrybucji wody Krakowa}

Aktualny podsystem dystrybucji wody buduje złożona sieć wodociągowa z licznymi zbiornikami wody czystej. Miasto Kraków podzielone jest na odrębne wodociągowe strefy zasilania $\mathrm{z}$ poszczególnych niezależnych źródeł, na które składają się cztery ujęcia wody powierzchniowej eksploatujące zasoby wodne rzek: Raby, Rudawy, Dłubnii i Sanki oraz jedno ujęcie wód podziemnych, znajdujące się w Mistrzejowicach. Lokalizacja i rozwiązania techniczne układów zasilania w warunkach normalnej eksploatacji zapewnia przeciętnie 169 tys. ${ }^{3}$ wody wtłaczanej do sieci, co gwarantuje niezawodne funkcjonowanie podsystemu dostawy wody do miasta. Woda w Krakowie dostarczana jest do odbiorców za pomocą złożonego układu rurociagów tranzytowych $(\varnothing 1400$, długość $18 \mathrm{~km})$, magistralnych $(\varnothing 1200-\varnothing 330$, długość $247,9 \mathrm{~km})$, rozdzielczych $(\varnothing 280-\varnothing 80$, długość $1131,1 \mathrm{~km})$ i przyłączy domowych $(\varnothing 100-\varnothing 25$, długość 472,9 km). Łączna długość sieci wodociagowej na terenie obsługiwanym przez MPWiK S.A. wynosi $1869,9 \mathrm{~km}$. Charakteryzuje się ona istotnym zróżnicowaniem wiekowym i materiałowym. Zdecydowanie największy udział $\mathrm{w}$ strukturze wiekowej posiadają rurociagi powstałe po roku 1975 (56\% całkowitej długości). Duża część tych przewodów wykonana została w latach dziewięćdziesiątych (26\% całkowitej długości), $\mathrm{z}$ zastosowaniem nowych technologii oraz materiałów, dzięki czemu ich 
wartość techniczna jest bardzo wysoka. Największy udział w budowie PsDyW mają przewody ze stali (32\% długości sieci) oraz kolejno przewody z żeliwa (26\%) i PCV (23\%). Nieodłącznym elementem PsDyW są zbiorniki wyrównawczo-zapasowe (11 obiektów) o łącznej pojemności ponad 276,2 tys. $\mathrm{m}^{3}$.

\section{Analiza niezawodnościowa pracy krakowskiego PsDyW}

Krakowski system dystrybucji wody jest układem dużym, rozległym o skomplikowanej topologii i zróżnicowanym uzbrojeniu. Stosunkowo częste awarie sieci wodociagowej są wynikiem wieloletniej eksploatacji rurociągów, negatywnego oddziaływania środowiska oraz nierzadko niskiej jakości materiałów, $\mathrm{z}$ jakich wykonywane były sieci $\mathrm{w}$ okresie powojennym.

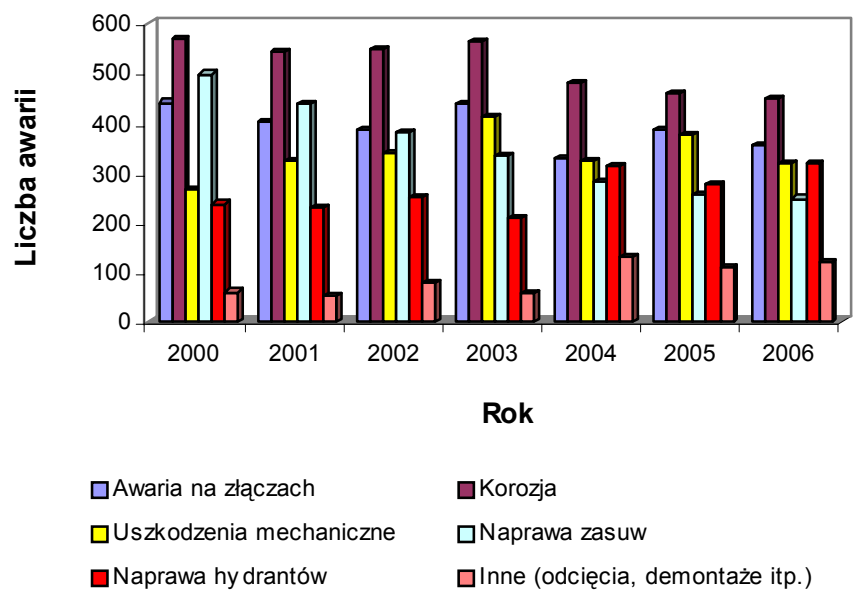

Rys.1. Awaryjność sieci wodociągowej w funkcji typu uszkodzenia - lata 2000-2006

W ciagu roku MPWiK S.A. Kraków odnotowuje przeciętnie 1850 awarii sieci wodociaggowj. Dotyczą one głównie uszkodzeń korpusu rury, złączy i uzbrojenia. Awarie te objawiają się najczęściej w postaci korozji (rys.1). Ponadto stwierdzono zależność intensywności uszkodzeń od pory roku, determinującej zarówno temperaturę gruntu jak i transportowanej wody. Zdecydowanie najwięcej awarii odnotowuje się w okresie jesiennozimowym. 
Analiza niezawodności funkcjonowania podsystemu dystrybucji wody

Tabela 2. Empiryczne wskaźniki niezawodności sieci wodociagowej Krakowa

\begin{tabular}{|l|c|c|c|}
\hline \multirow{2}{*}{ Wskaźnik } & \multicolumn{3}{|c|}{ Przewody stalowe } \\
\cline { 2 - 4 } & Przyłącze domowe & Sieć rozdzielcza & $\begin{array}{l}\text { Magistrala } \\
\text { i tranzyt }\end{array}$ \\
\hline $\boldsymbol{T}_{\boldsymbol{p}[\mathbf{h}]}$ & 453,13 & 444,19 & 1413,82 \\
\hline $\boldsymbol{\omega}\left[\mathbf{a}^{-1} \mathbf{k m}^{-1}\right]$ & 0,292 & 0,342 & 0,028 \\
\hline $\boldsymbol{T}_{\boldsymbol{o}}[\mathbf{h}]$ & 26,05 & 29,05 & 47,41 \\
\hline $\boldsymbol{T}_{\boldsymbol{n}}[\mathbf{h}]$ & 7,41 & 9,24 & 8,77 \\
\hline $\boldsymbol{T}_{\boldsymbol{z}}[\mathbf{h}]$ & 18,65 & 19,81 & 38,64 \\
\hline $\boldsymbol{\mu}\left[\mathbf{h}^{-1}\right]$ & 0,038 & 0,034 & 0,021 \\
\hline $\boldsymbol{R}(\boldsymbol{t})$ & $R(t)=\exp (-0.00221 \cdot t)$ & $R(t)=\exp (-0.00225 \cdot t)$ & $R(t)=\exp (-0.0007 \cdot t)$ \\
\hline \multicolumn{3}{|c|}{ Przewody $\dot{\boldsymbol{z}}$ eliwne } \\
\hline $\boldsymbol{T}_{\boldsymbol{p}[\mathbf{h}]}$ & 448,92 & 42,86 & 543,58 \\
\hline $\boldsymbol{\omega}\left[\mathbf{a}^{-1} \mathbf{k m}^{-1}\right]$ & 1,698 & 1,053 & 0,422 \\
\hline $\boldsymbol{T}_{\boldsymbol{o}}[\mathbf{h}]$ & 25,49 & 38,82 & 52,40 \\
\hline $\boldsymbol{T}_{\boldsymbol{n}}[\mathbf{h}]$ & 6,56 & 6,85 & 8,13 \\
\hline $\boldsymbol{T}_{\boldsymbol{z}}[\mathbf{h}]$ & 18,92 & 31,97 & 44,27 \\
\hline $\boldsymbol{\mu}\left[\mathbf{h}^{-1}\right]$ & 0,039 & 0,026 & 0,019 \\
\hline $\boldsymbol{R}(\boldsymbol{t})$ & $R(t)=\exp (-0.02218 t)$ & $R(t)=\exp (-0.02333 \cdot t)$ & $R(t)=\exp (-0.00184 \cdot t)$ \\
\hline
\end{tabular}

Przeprowadzona analiza niezawodnościowa koncentrowała się na ocenie i klasyfikacji warunków funkcjonowania podsystemu dystrybucji Krakowa. Badania eksploatacyjne niezawodności prowadzone były w latach 20042006 w ramach realizacji projektu badawczego PB nr 5T07E 04425 [5]. Ponadto analize oparto na danych archiwalnych (1996-2006) zawartych w Kartach eksploatacyjnych sieci wodociagowej krakowskiego SZW uzyskanych w przedsiębiorstwie wodociągowym [2]. Badaniami objęto sieć wodociągowa o łącznej długości 1869,9km,z zakresu średnic od Ø25 do Ø1400. Ustalone warunki badań gwarantowały, wyznaczenie miar niezawodnościowych $\mathrm{z}$ dokładnością $\delta=0,1$ (błąd względny) na poziomie wiarygodności $\beta=0,95$. Badania prowadzono $w$ dwóch kierunkach. Pierwszy kierunek badań obejmowała analizy niezawodnościowe sieci wodociagowej ze względu na materiał ją budujący oraz funkcję, jaką pełni $\mathrm{w}$ dystrybucji wody $\mathrm{w}$ mieście tzn. uwzględniając podziała sieci wodociaggowej na sieć rozdzielczą, magistralną i tranzytową ora podłączenia domowe (tabela 2). Drugi aspekt prac badawczych to wstępna ocena niezawodności wyodrębnionych elementów linowych systemu dystrybucji.

Dla każdego przewodu o określonej średnicy, wykonanego z konkretnego materiału obliczono następujące realizacje zmiennych losowych $\mathrm{w}$ funkcji: 
czasu bezuszkodzeniowej pracy $T_{p}[\mathrm{~h}]$, czasu odnowy $T_{o}[\mathrm{~h}]$, czasu naprawy $T_{n}[\mathrm{~h}]$ i czasu oczekiwania na naprawę $T_{z}[\mathrm{~h}]$. Wszelkie analizy statystyczne zmiennych losowych przeprowadzono wykorzystując procedury obliczeniowe pakietu programu komputerowego STATISTICA PL. Wyniki testu Kruskala-Wallisa weryfikacji hipotezy $\mathrm{H}_{0}$ zakładającej rodzaj nawierzchni jako czynnik jednoznacznie określający przynależność badanej próby do zbiorowości generalne, potwierdziły słuszność przyjętych założeń. Tak zweryfikowane zmienne losowe stanowią więc materiał wyjściowy do wyznaczenia empirycznych charakterystyk niezawodności (tabela 2)

Uzyskane wyniki analizy uszkadzalności sieci odniesiono do zalecanych standardów europejskich określających intensywność uszkodzeń dla:

- sieci magistralnej - 0,3 uszk/axkm,

- sieci rozdzielczej - 0,5 uszk/axkm,

- przyłącza domowe - 1,0 uszk/axkm.

Analizując w latach 2000-2006 proces uszkodzeń sieci w funkcji materiału mającego największy udział w całkowitej długości systemu (32\%) tj. stali, można jednoznacznie stwierdzić, że charakteryzuje się on bardzo wysoką niezawodnością $\mathrm{w}$ odniesieniu do przewodów tranzytowych i magistralnych spełniającą powyższe standardy europejskie $\left(\omega_{s t} T M=0,028\right.$ uszk/axkm $<\omega_{w}(t)=0,3$ uszk/axkm). Dla pozostałych stalowych przewodów sieci wskaźnik awaryjności spełnia również standardy europejskie: sieć rozdzielcza 0,342 uszk/axkm oraz podłączenia domowe 0,292 uszk/axkm. Przeprowadzając analizę dynamiki i charakteru zmian niesprawności sieci jednoznacznie można stwierdzić zmniejszenie uszkadzalności sieci W odniesieniu do okresu przed 2000 rokiem . W latach 1996-1999 parametr strunienia uszkodzeń przyjmował odpowiednio wartości: sieć tranzytowa i rozdzielcza - 0,095 uszk/axkm, sieć rozdzielcza 0,699 uszk/axkm oraz przyłacza domowe 1.434 uszk/axkm [4]. Po wdrożeniu w 2001 roku systemu zarządzania siecią, opartego na analizach i wnioskach archiwalnych danych eksploatacyjnych dotyczących awarii, intensywność uszkodzeń stalowej sieci rozdzielczej zmalała średnio aż o 65\% w ciągu zaledwie 6 lat. Przeprowadzone badania w odniesieniu do żeliwa (tabela 2), wykazały iż materiał ten charakteryzuje się nadal bardzo wysoką awaryjnością. W latach 1996-1999 intensywność uszkodzeń dla poszczególnych typów sieci wynosiła odpowiednio:

- sieci magistralnej - 0,867 uszk/axkm,

- sieci rozdzielczej - 2,239 uszk/axkm,

- przyłącza domowe - 1,695 uszk/axkm.

Analiza dynamiki zmian w odniesieniu do żeliwa wykazała obniżenie po 2000 o 52\% intensywności uszkodzeń dla sieci rozdzielczej jak i 
magistralnej. Jedynie dla przyłączy domowych w całym horyzoncie badań (lata 1996-1999 oraz 2000-2006) wyznaczona intensywność uszkodzeń jest wysoka i utrzymuje się na stałym poziomie 1,698 uszk/axkm.

W celu identyfikacji rozkładu rozpatrywanych zmiennych losowych dla poszczególnych sieci, weryfikowano poprawność przyjętej hipotezy zerowej, na poziomie istotności $\alpha=0,05$, że czas pracy bezuszkodzeniowej $T_{p}$ ' i czas odnowy $T_{o}$ ' mają rozkład wykładniczy. Do weryfikacji przyjętych hipotez zastosowano test $\chi^{2}$-Pearsona. Ponieważ wyliczone, dla każdego przypadku analizy, wartości statystyki $\chi^{2}$ były mniejsze od wartości krytycznych, dlatego nie ma podstaw do odrzucenia przyjętych hipotez. Analizy powyższe umożliwiły na określenie równań prawdopodobieństwa pracy bezuszkodzeniowej (tabela 2).

\section{Podsumowanie}

1. Zdecydowanie największa uszkadzalnością charakteryzują się przewody żeliwne

2. O niezawodności PsDyW wykonanego z żeliwa decydują głównie uszkodzenia złączy. W krakowskim podsystemie dystrybucji przewody żeliwne są stare $\mathrm{z}$ dobiegającym końca okresem trwałości technicznej (36\% sieci osiągnęła wiek z przedziału 25-50 lat). Większość z nich była łączona na kielichy uszczelniane tradycyjnie sznurem i folią aluminiowa, których intensywność uszkodzeń jest wyższa od połączeń z zastosowaniem nowoczesnych technologii.

3. W odniesieniu do europejskich standardów uszkadzalności sieci wodociągowej jedynie sieć rozdzielcza i przyłącza wodociągowe wykonane z żeliwa nie spełniają wymaganego poziomu niezawodności.

4. Uszkadzalność żeliwnej sieci rozdzielczej jest ponad dwukrotnie wyższa $(\omega=1,053$ uszk $/ a x k m)$, a przyłączy domowych trzykrotnie $(\omega=1,698$ uszk/axkm), w odniesieniu do intensywności uszkodzeń sieci magistralnej i tranzytowej $(\omega=0,422$ uszk/axkm). Natomiast dla stalowych magistrali intensywność uszkodzeń jest średnio jedenastokrotnie niższa $\mathrm{w}$ odniesieniu dosieci rozdzielczej i przyłaczy domowych.

5. Z niezawodnościowego punktu odniesienia można jednoznacznie stwierdzić, że ogólnie sieć wodociaggowa charakteryzowała się dużą zmiennością gotowością do pracy $\mathrm{w}$ odniesieniu do poszczególnych typów sieci. Średnia wartość stacjonarnego wskaźnika gotowości dla przewodów sieci magistralnej i tranzytowej wynosił 0,940010 oraz dla przyłączy domowych 0,945953 . W przypadku sieci rozdzielczej wartość 
tego parametru osiagnęła najmniejszy poziom 0,7316435 , co wynika z dużej awaryjności przewodów o średnicy 100 i $150 \mathrm{~mm}$.

6. Ilościowa ocena negatywnych zdarzeń eksploatacji sieci wodociagowej pozwala na sprecyzowanie racjonalnych wniosków i zastosowanie działań technicznych mających na celu ich eliminację. Stąd też, stosowanie zaprezentowanej analizy niezawodności pracy sieci wodociagowej, w odniesieniu do ich struktury technicznej, stanowi nie tylko wartość poznawczą aplikacji teorii niezawodności w branży wodociaggowej ale również istotną informację praktyczną dla racjonalnego zarządzania systemem zaopatrzenia w wodę.

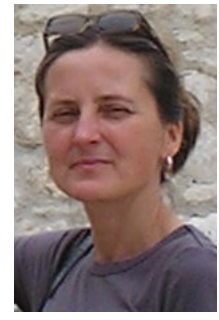

PhD Eng Zimoch Izabela - the doctor on Silesian University of Technology in Gliwice, Institute of Water and Sewage Engineering. Specialist in Research and Technology Development at Department of Water Technology Upper Silesian Waterpipe Company. Specialization: civil engineering, water treatment, reliability and risk analysis of water supply system. 